
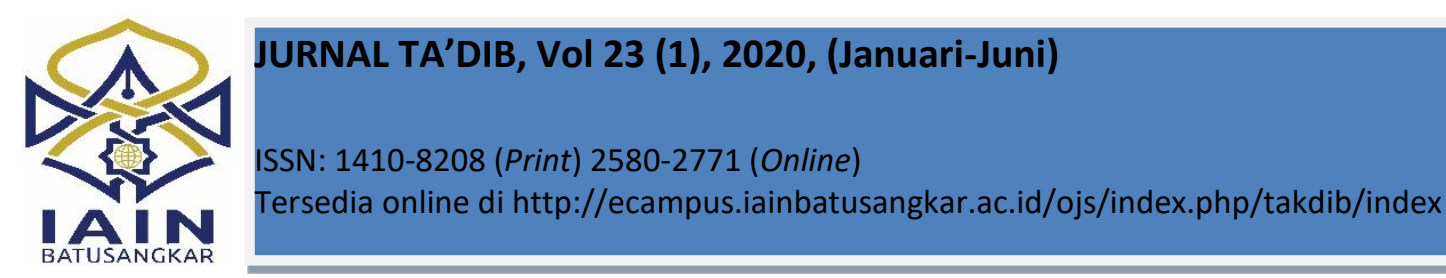

\title{
Smart Parenting in Improving Students' Spiritual Intelligence in Pesantren-based Madrasahs
}

\author{
Zamroni*) \\ Institut Agama Islam Negeri Samarinda, \\ Kalimantan Timur, Indonesia \\ E-mail: iceisa.iainsmd18@gmail.com
}

\begin{abstract}
Abctract: Smart parenting is a pattern of children's education, that parents or caregivers accompany and guide the growth of children towards the creation of a golden generation in accordance with the expectations of all parties. The focus of this research lies in the effort to implement smart parenting in improving the spiritual intelligence of students at MTs Nabil Husein Samarinda and MTs Al Mujahidin Samarinda. This research used a qualitative approach with case study. The results show that the implementation of smart parenting in improving the spiritual intelligence of students at MTs Nabil Husein Samarinda and MTs Al Mujahidin Samarinda is carried out in a planned and systematic manner. The steps taken to implement smart parenting were; 1) planning smart parenting activities designed by the madrasah by involving all existing components, 2) implementng smart parenting as a form of implementation of the existing planning design, and 3) evaluating smart parenting activities with the principles of openness, objectivity and based on continuous improvement. The results of these activities appear on the students' discipline behavior, adherence to existing regulations and responsibility.
\end{abstract}

Keywords: Smart Parenting, Spiritual Intelligence, Madrasah

\section{INTRODUCTION}

N piritual intelligence is intelligence where humans put their behavior and and mo comprehens meaning (Sukidi, 2002). This intelligence is very important possessed by each individual, although in essence humans are more glorifying the ability of the brain/reason (IQ) than this spiritual intelligence. This mindset has given birth to many educated generations with intelligent brain capacities, but their behavior, attitudes and lifestyle are in sharp contrast to their intellectual abilities. Many people who have IQ intelligence did not succeed, even failed in work and life. They have a split personality, which causes no integration between the brain and heart (Rahmawati, 2016).
Due to the importance of spiritual intelligence, MTs Nabil Husein Samarinda and MTs Al Mujahidin Samarinda, strive to strengthen the spiritual intelligence of students to be able to adapt to the development of science and have mental and spiritual endurance amid the onslaught of modernization (Sukino, 2019). The targeted spiritual intelligence is the ability of individuals to act and behave easily to adapt to their environment, flexible, have a high level of awareness, able to take valuable lessons and lessons from an event and failure, able to see the relationship of one thing to another, be independent, able to realize life as you wish, and make someone understand the meaning of his life.

This effort was realized through the hard work of all madrasah components that 
synergized with pesantren (Kesuma, 2017) to improve spiritual intelligence through smart parenting at MTs Nabil Husein Samarinda and MTs Al Mujahidin Samarinda as part of education autonomy (Rifa'i, 2017). The madrasah is aware that students (santri) who stay away from their parents are "lacking attention and affection". Consequently, the extra role of the teacher is needed as a substitute for their parents in the practice of caring.

Smart parenting is a smart behavior or action carried out by adults to children in order to educate, protect, teach, discipline, care for and provide guidance (Jennah, 2019). In interacting with their environment, sometimes there is a tendency that influences children, both in terms of style of speech, knowledge, behavior, and lifestyle (Astuti, 2014). Smart parenting is also understood as an education strategy for children, where parents as madrasatul ula (the first school) accompany and guide all stages of child growth, which care for, protect, direct the new life of children in each stage (Rozana et al., 2017).

This shows that parenting includes several understandings, including: (a) care aims to encourage optimal growth and development of children, both physically, mentally as well as socially, (b) nurturing is a process of interaction that is carried out continuously between parents and children, (c) care is a process of socialization and interaction, (d) care can not be separated from the sociocultural factors in which children begin to grow and grow up (Muallifah, 2013).

The madrasah realizes that children are the next generation who will continue the struggle to achieve the ideals of the nation and will be the nation's leaders in the future. For this reason, caring for children in the most important period (golden age) requires a golden parenting pattern as well, bearing in mind that this golden period only happens once and will not repeat itself. This is as compared to by Ozaria (2018) in his research on smart parenting education carried out in PAUD Integrated Arraisyah Bangka
Belitung. The results of his research showed that parenting education went well according to directions and from the Director General PAUDNI.

Likewise, Baharun and Finori (2019) investigated smart techno parenting in educating children in the digital age. The results of their research indicate that there is a need for synergy between technological advances and children's education in order to be able to optimize children's activities and potential. In addition, parents need an active role in choosing technology and intensive media in monitoring children's development.

In addition to this, Ashshidieqy (2018) states that spiritual intelligence is very influential in students' learning achievement. Of all the multiple intelligences available, spiritual intelligence is the intelligence that represents it and covers all aspects of life.

Aridhona (2017) in his research also concluded that; there is a positive relationship between spiritual intelligence and emotional maturity with self-adjustment which means the higher the spirituality and emotional maturity, the higher the self-adjustment teenagers have.

Research on spiritual intelligence as an output of the educational process was delivered by Mukhasin (2014) who studied the Development of Spiritual Intelligence at the Al-Hikmah Islamic Boarding School in Arjomulyo Kebumen. The results of his research show that the development of spiritual intelligence of students of Pesantren Al-Hikmah Arjomulyo Adimulyo Kebumen is done by means of Al-Hikmah breathing exercises, relaxation meditation, and dzikir. Likewise, Mahmudah (2016), examined the Relationship Between Spiritual Intelligence and Santri Personality in Pesantren Alhidayah Karangsuci Purwokerto. The results indicates that there is a correlation between spiritual intelligence and the personality of santri Pesantren AlHidayah Karangsuci Purwokerto accepted the truth.

From the studies above, it clearly shows that spiritual intelligence as the ultimate goal needs serious attention, so an effective 
parenting model is needed, namely smart parenting. The researcher in this case tries to understand the meaning of smart parenting on the increase in spiritual intelligence of students, whose notes are far from biological parents, but they still get the attention and care of foster caregivers as a substitute for the role of parents for students in MTs Nabil Husein Samarinda and MTs Al Mujahidin Samarinda based on pesantren.

Smart parenting in improving students spiritual intelligence in pesantren-based Madrasah is a novelty of this research, considering pesantren-based Madrasah is an educational model that is able to develop multiple intelligence (compound intelligence) (Nurochim, 2016), spiritual-religious, life skills, and strengthening national character (Zulfaizah, 2018); (Arif \& Pratama, 2019).

At the implementation level, pesantrenbased Madrasah is a superior education model that integrates an implementation of the school system that focuses on developing scientific abilities and skills with the implementation of a pesantren system that is focused more on developing religious attitudes and practices, increasing morality as well as independence in living life.

This research discusses the effort to implement smart parenting in improving the students' spiritual intelligence at MTs Nabil Husein Samarinda and MTs Al Mujahidin Samarinda.

\section{METHOD}

This research used a qualitative method with case study. The purpose of this study was to obtain in-depth description and understanding of the effort to implement smart parenting in improving the spiritual intelligence of students at MTs Nabil Husein Samarinda and MTs Al Mujahidin Samarinda. Data collection techniques in this study were carried out circularly; 1) in-depth interview conducted using purposive sampling technique. This means that the researcher chose informants consisting of leaders of madrasah institutions, madrasah deputy heads, santri guardians, and students to obtain data on implementing smart parenting in MTs Nabil Husein Samarinda and MTs Al Mujahidin Samarinda. 2) observation of various educational and learning activities, both directly and indirectly carried out by teachers and caregivers at the institution. 3) Documentation. While the data analysis was done circularly, namely; data reduction, data presentation, and drawing conclusions or verification.

\section{RESULTS AND DISCUSSION}

Basically, humans are created by carrying the elements of intelligence. Initially, the intelligence understood by many people was only intellectual intelligence. Along with the development of human knowledge, other types of intelligence are discovered through empirical and longitudinal studies by academics and psychology practitioners, including spiritual quotient.

To improve spiritual intelligence, MTs Nabil Husein Samarinda and MTs Al Mujahidin Samarinda implement smart parenting programs, which are carried out in a planned and systematic manner by involving various parties, including teachers and students' families. This is because the family is the first place for education and learning. If family life is fostered well, then community life will be good too. Through the family, it is expected that children and other family members can grow and develop according to their ability to become someone who is independent and can be a productive person for themselves and their environment.

The steps taken to implement smart parenting in MTs Nabil Husein Samarinda and MTs Al Mujahidin Samarinda are as follows:

\section{a. Smart Parenting Design}

Smart parenting implemented at MTs Nabil Husein Samarinda and MTs Al Mujahidin Samarinda is the result of the design of the madrasah strategic plan in achieving its vision and mission. The planning process is a process in which the madrasah prepares everything needed when implementing activities and aims 
for the success of a program or activity to carry out. Planning is the process of determining the goals or objectives to be achieved, determining the paths and resources needed to achieve goals as effectively as possible. This is in line with the planning carried out at MTs Nabil Husein Samarinda and MTs Al Mujahidin Samarinda, where the planning process is carried out by madrasah managers, educators and parents.

The madrasah planning to increase the spiritual intelligence of students in MTs Nabil Husein Samarinda and MTs Al Mujahidin Samarinda was done through smart parenting namely; the smart parenting program in the madrasah annual work plan, then implement it in the madrasa curriculum and make it a culture within the MTs Nabil Husein Samarinda and MTs Al Mujahidin Samarinda.

Smart parenting was technically carried out through the following stages: (1) coordinating and meeting with the student's guardian at the beginning of each semester, (2) holding a meeting with the student's guardian and holding regular recitation, (3) doing a regular meeting with the student's guardian at the time of receiving a report card. In this meeting the discussion and questions \& answers about the achievements during the semester run well. These activities can be used as an evaluation by the guardians of students to what extent their success in parenting by making report cards and homeroom reports as instruments.

The material presented in the meeting with the guardians of the students were; an introduction to smart parenting, the importance of cooperation to create successful children, types of good and ideal parenting, and spiritual reinforcement for children and parents. The material is given to the guardians of students with the aim of being able to understand how parenting should be applied to their children, which matches their child's personality.

The method used in smart parenting activities when having meeting between student guardians and the madrasa component used various methods such as lecture, discussion, problem solving and question and answer. These methods were effective because the target of this parenting activity could be wellachieved.

The media used in smart parenting activities were LCD projector, poster about parenting, so that young people are understood by parents, smart bags containing short words how to take good care of children based on the age of the child. In addition, the contact book was used as a tool to communicate between parents and the school parties.

Smart parenting is used as a madrasah program in addition to supporting students in increasing intelligence as well as being able to better achieve the ideals or expectations of parents towards their children.

\section{b. Implementation of Smart Parenting}

The implementation of smart parenting is an application in the form of real activities from what has been determined in the planning stage. Likewise, in the process of implementing the parenting program at MTs Nabil Husein Samarinda and MTs Al Mujahidin Samarinda was carried out through a planning process in advanced.

The implementation of smart parenting in enhancing the spiritual intelligence of students at MTs Nabil Husein Samarinda and MTs Al Mujahidin Samarinda was carried out in the form of three care, namely physical care, emotional care, and social care. Physical care is applied to students in terms of building children's character, such as honest character, noble character, discipline in all activities in the madrasa, both in the classroom and outside the 
classroom. Physical care is carried out by involving all components of the madrasa and making standard rules about this activity, such as; smile, greetings and greetings.

Physical care implemented in madrasah includes activities to empower students to survive and be able to adjust to their environment. All madrasah components in MTs Nabil Husein Samarinda and MTs Al Mujahidin Samarinda work collaboratively to educate, foster, direct and monitor the students' physical development. In this case, the teacher becomes the frontline in educating and caring for children to have the desired spiritual intelligence and character. Through physical care, students feel cared for and get affection like at home, so that they feel comfortable and feel at home studying in madrasah.

Emotional care is carried out during a meeting between the teacher and the students' guardian during the distribution of report cards. In this activity, teachers and guardians of students share about the development and problems encountered in educating and involving students, both in learning activities in the classroom or outside the classroom, as well as other matters relating to the child's development. In addition, guardians of students are allowed to get to know their students' behavior when in the madrasah, through providing objective information about child development, so that they know about matters of their child's development directly and contribute to the improvement of students in accordance with the expectations of all parties. It is intended that the guardians of students understand parenting and ideal strategies in educating children through the smart parenting approach.

Emotional care implemented at MTs Nabil Husein Samarinda and MTs Al Mujahidin Samarinda aims to make students feel confident and feel valued as an individual, have a stable and consistent ability to interact with their environment, and have the opportunity to make choices and find out the risks, create a sense of optimism for the new things that it faces.

Through emotional care, parents and teachers are expected to be able to work together intensively in paying attention to the students' development periodically when children experience various life problems, both pleasant and unpleasant experiences, have a disability in learning, feel alienated or experience things that are psychological.

The third care is social care, where social care is intended to make students feel at home and comfortable living in madrasah, both in learning activities and other activities. They don't feel alienated from their environment, but they are actually able to contribute to their environment.

Social care implemented in MTs Nabil Husein Samarinda and MTs Al Mujahidin Samarinda through the smart parenting approach is done directly or indirectly by all madrasah components, such as providing understanding to students about the importance of social interaction, good manners, how to socialize with teachers, friends and parents, and ways to avoid something that is not in accordance with existing ethics and social norms.

Another thing that is done by madrasah leaders at MTs Nabil Husein Samarinda and MTs Al Mujahidin Samarinda was to make this care integrated in the curriculum activities in madrasah, such as the use of cooperative learning, inquiry, small group discussion and others. This activity is intended so that children can be comfortable in socializing and interacting with other friends. As a result they would give a positive meaning to each other in their interactions, both in the classroom and outside the classroom. 


\section{c. Smart Parenting Evaluation}

The evaluation process is a measuring tool to find out how far the goals of a program can be achieved. This process in the parenting program can be said as a form of assessment of an activity that has been carried out. Evaluation of activities is an attempt to measure and give an objective value on the achievement of the results of the implementation of smart parenting activities that have been planned before at MTs Nabil Husein Samarinda and MTs Al Mujahidin Samarinda. Evaluations include to question the effectiveness and efficiency of the implementation of a plan. In addition, the evaluation also measures the results of the implementation objectively with a size that can be accepted by all parties concerned. The form of evaluation of the smart parenting program at MTs Nabil Husein Samarinda and MTs Al Mujahidin Samarinda was carried out twice, namely at the end of parenting program activities towards parents which were manifested in the form of discussions and questions and answers to find out how parents understand in receiving and understanding the material conveyed. While the evaluation of smart parenting program activities is carried out in a small meeting or discussion involving educators and managers. The evaluation covers the entire program component and the whole process of implementing the parenting program. Evaluation is carried out to improve and improve the quality of subsequent programs to be even better.

From the implementation of smart parenting above, it provides optimal results in increasing the spiritual intelligence of students. Increasing the spiritual intelligence of students in MTs Nabil Husein Samarinda and MTs Al Mujahidin Samarinda can be seen from several aspects. First, the growth of the discipline of children in every activity in madrasah, both in learning activities in the classroom and outside the classroom, personal development activities, and skills development activities. In this case, spiritual intelligence provides a major contribution to the improvement of students' discipline in daily life.

The ability of students to interpret the meaning of a discipline in their lives is very important, because to build self-discipline is not an easy task. It takes high self-awareness in building self-discipline for students. Discipline with self-awareness motives will be better and stronger. While discipline that is not sourced from self-awareness, will result in weak discipline and cannot last long. Students who are less able to interpret discipline will feel burdened by the rules in the madrasah. They follow the existing rules of the madrasah by force and often even violate the existing rules, so they cannot understand the main purpose of every regulation made and determined by the madrasah.

Discipline in students in the two madrasahs cannot be achieved without instilling discipline through the educational process, especially through smart parenting activities. This is because good discipline grows from within the child as an element of habit. In this regard, teachers at MTs Nabil Husein Samarinda and MTs Al Mujahidin Samarinda have a very large role in the cultivation of children's discipline in schools, because teachers are educators as well as people who are directly involved in inculcating children's attitudes and habits in order to have self-discipline. Teachers and parents must know and understand the learning process that is appropriate to their child's development, both at home and at school, and for the sake of continuity of the learning process itself, so that it becomes a habit that is owned by the child

Secondly, an increase in students' spiritual intelligence is also seen in their adherence to the existing and enforced regulations. This also happened after the implementation of smart parenting by their parents at home. Good spiritual intelligence will bring students to understand about why is a regulation made? Can the regulation be changed or improved? 
Spiritual intelligence will complement students in solving problems, directing thoughts and actions in life towards broader and more meaningful horizons, and directs to be able to distinguish more clearly about right from wrong. Good spiritual intelligence will affect the quality of life of students. With the existence of good spiritual intelligence, the students will be able to interpret life more broadly and richer, able to adjust to existing regulations, produce good performance in every work done.

Third, students are able to take responsibility for the mandate given, such as getting the mandate to become a dzikir reader before prayer begins at the madrasah. It is also caused by parenting that has influenced the behavior of students, so they have empathy, conscience and are able to control themselves.

Caring approaches done through the smart parenting at MTs Nabil Husein Samarinda and MTs Al Mujahidin Samarinda can help students understand the feelings of others, so that they are able to interact and contribute amidst the heterogeneity of existing students. This makes students' sensitivity to the needs and feelings of others, and encourages them to help people who need help, and treat everyone with affection.

In addition, smart parenting which is oriented to the spiritual intelligence of students, makes students have a conscience that is always ready to help and help others in every opportunity, making students choose the right path in each of their activities, and stay on the moral path and make himself feel guilty when deviating.

This policy is the foundation of honesty, responsibility, and high self-integrity. Helping the students resist the inner urge and think before acting, so that they do the right things. This virtue makes students independent. This trait will evoke the character of cheap and kind and not selfish.

Students at MTs Nabil Husein Samarinda and MTs Al Mujahidin Samarinda can instill a sense of responsibility in themselves towards the tasks they carry, as a form of self- service. The responsibility of students in this case is as a student who must study well, earnestly, do the assignments that have been given to him, discipline in undergoing school discipline and Islamic character.

Theoretically, the implementation of smart parenting refers to the concept of learning design that is oriented towards maximum results (Baharun, 2018), which starts from the planning, implementation and evaluation of learning outcomes (Saufi \& Hambali, 2019), in order to obtain a feedback that is intended as continuous improvement (Mahmud \& Suratman, 2019).

Parenting is a popular term that focuses on child rearing. Parenting is understood as an activity aimed at the progress and development of a child (Sri W Rahmawati, 2017). Parenting activities are carried out in the family, because the family is the first place where a child gets an education and is the smallest unit in society (Abdurahman, 2017). To realize a function of a more extended family, especially the function of the family in the social and educational fields, parenting activities are carried out between the school and the family so that the family can work together and become good partners (Heru Kurniawan, 2016).

In general, parenting aims to invite parents to be together in providing the best education for children. Parenting programs can increase a parent's knowledge and skills in performing care, nurturing (Heru Kurniawan, 2016), and in conducting education of children in a family based on the foundations of good character (Maryam, 2018); (Abdi, 2018).

In principle, parenting is parental control, which is how parents control, guide, and assist children in carrying out various tasks for their development towards maturity. Parenting is a way for parents to interact with children which consists of giving gifts, giving rules, giving penalties and giving attention, and parental responses on each child's behavior (M. Burhanuddin Ubaidillah, 2019).

Smart Parenting as a new innovation in children's education, is an educational strategy for children, where parents as 
madrasatul ula (first school) in assisting and guiding at all stages of a child's growth, as well as protecting, caring for, and directing a new life for children at each stages (Jennah, 2019). Smart parenting is a variety of fairly intelligent actions being carried out by both adults and parents towards children with the aim of caring for, protecting, teaching, disciplining and providing guidance. When interacting with an environment, sometimes there is a tendency that affects children, whether related to knowledge, behavior, style of speech, or about lifestyle (Rozana et al., 2017).

If a child has begun to interact with the outside world, then supervision and assistance of parents in this situation is needed for optimal child growth and development (Astuti, 2014). Smart Parenting is also defined as a whole thing that can be done by parents, things that are categorized as big or small, which take place from day to day, which can then create a healthier balance in a household and interaction with children.

In addition, smart parenting as part of parenting (Yuki Widiasari, 2017), aims to increase the awareness of parents as educators first and foremost, to increase the knowledge, attitudes and skills of parents / family in caring for, protecting, and educating children, to increase parental / family support in the educational process of children in educational institutions and in community environment (Setijaningsih \& Matiningsih, 2014). In addition, the noble goals of smart parenting are: (1) Improving the ability of parents in terms of techniques to support the learning process of their children, so that they can optimally support their children's development. (2) Applying children's learning abilities in daily life, so that it becomes one of life skills.

Smart Parenting has principles that serve as a foundation in building a wise family, among others: first, realizing the feelings of yourself and others, second, show empathy and understand the perspectives of others, third, manage emotional and behavioral turmoil wisely, fourth, oriented on the objectives and determination of a good plan, fifth, make use of a social skill in all types of relationships (Candra, 2017).

Spiritual intelligence is the intelligence of the soul. Spiritual intelligence can help humans heal and build themselves fully. Spiritual intelligence is the intelligence of a person in managing and utilizing the meanings, values, and qualities of his spiritual life. Spiritual life here includes; desire to live meaningfully, which motivates human life to always look for the meaning of life and long for a meaningful life (Sabiq \& Djalali, 2012).

There are four indicators in spiritual intelligence, among others: (1) Critical existential thinking is the ability to think critically about issues such as meaning, purpose, existence, death, ability to deal with conclusions, ability to think about non issuesexistence from an existential perspective. (2) Personal meaning is the ability to carry out meaning and personal goals in all material and physical experiences, including the ability to create goals in life. (3) Transedental awareness is the ability to recognize dimensions and abilities of self-excellence (internal and external transformation). (4) Expansion of the area of awareness is the ability to enter the highest level of spirituality (Wibowo, 2015).

The spirituality dimension of understanding and appreciation of diversity is basically a journey towards human beings themselves. It would be very possible that a modern human being who has a variety of super sophisticated living facilities would be poor in his wandering in knowing his inner dimensions (Naim, 2014). There are various methods that can be done in educating this heart. First, as religious people, spiritual intelligence takes a vertical method, namely how spiritual intelligence can educate the heart to establish a close relationship with the presence of God. Dzikir is a method of spiritual intelligence in educating the heart to be calm and peaceful. As the locus of human consciousness, a calm heart has direct implications for the calmness, maturity, and rays of wisdom that will radiate in everyday 
life. Second, the implication is horizontal. Spiritual intelligence educates the heart into good character and civilized morals (Baharun, 2017). In the midst of the current demoralization which is a human behavior lately, a spiritual intelligence is not only effective in treating human behavior that is quite destructive, but will also be human guidance in treading life in a polite and civilized way (Sukidi, 2004).

To achieve life balance, spiritual intelligence is absolutely necessary. With SQ, humans are then expected to be able to optimize their intelligence and potential. Some of the benefits of SQ for an individual are; (1) Foster the development of the human brain. (2) Generating creativity. (3) Providing abilities is flexible. (4) Making intelligent with spiritual in religion. (5) Unifying interpersonal and intrapersonal. (6) Achieve personal development. (7) Able to distinguish between right and wrong (Ani Agustiyani Maslahah, 2013).

Discipline as part of the spiritual intelligence section is understood as a strict observance that is supported by awareness to carry out the duties and obligations as they should according to the rules or codes of conduct that should apply in a certain circle (Haryono, 2016). The realization must be seen in the actual action or behavior, that is the behavior that is in accordance with the rules or proper conduct.

Likewise with students' adherence to existing regulations, is an awareness of the benefits of regulations, which then gives birth to a form of loyalty to the values of the regulations that are enforced in a shared life and manifested in the form of real behavior (Kurniasih, 2014). A person will obey the rules, if he is aware that the rules serve to protect the interests of humans both as individuals and as social beings. Obedience is an active attitude based on motivation after he has gained knowledge.

While the attitude of responsibility is human awareness of behavior or intentional or unintentional actions. Responsibility also means acting as an expression of awareness of its obligations (Anwar, 2014). Responsibility has become part of human life that every human being must be burdened with responsibility.

The results of this study provide reinforcement to several previous studies, as mentioned above. This shows that smart parenting has an extraordinary influence on the spiritual intelligence of students in madrasah based on pesantren.

\section{CONCLUSION}

Madrasah as an Islamic educational in pesantren have more bargaining value because this institution seeks to integrate the advantages of the madrasah education system with the organization of education in pesantren. Pesantren-based Madrasah is one model of Islamic education that integrates two social systems, namely social systems in pesantren and social systems in schools that is intended to create a human resource that is religious as well as a scientist as a whole, so that it can play a full role in the social system.

Smart parenting which is implemented in a planned, systematic and sustainable manner would provide optimal results in increasing students' spiritual intelligence in Pesantrenbased Madrasah. The result of spiritual intelligence would complement students in solving problems, strengthen thoughts and actions in life towards a broader and meaningful horizon, and lead to be able to distinguish between right and wrong. Through this intelligence, students will get physical and inner peace, so that they can interpret life more broadly and meaningfully.

This research focuses on a small environment. Considering only focused on pesantren-based Madrasah as educational institutions, it is suggested that further research is needed as a development of this research. This research provides new insights on the importance of parenting through a parenting approach that must be carried out by all educators, both religious and non-religious based educational institutions in enhancing spiritual intelligence. 


\section{REFERENCES}

Abdi, M. I. (2018). The Implementation of Character Education in Kalimantan, Indonesia: Multi Site Studies. Dinamika Ilmu, 18(2), 305-321. https://doi.org/10.21093/di.v18i2.1289

Abdurahman. (2017). Implikasi UUSPN Terhadap Pendidikan Islam. Al-Tanzim: Jurnal Manajemen Pendidikan Islam, 1(1), 19-35.

Agustian, G. (2001). Rahasia Sukses Membangun Kecerdasan Emosi \&Spiritual: Berdasarkan 6 Rukun Iman \&5 Rukun Islam. Arga.

Ani Agustiyani Maslahah. (2013). Pentingnya Kecerdasan Spiritual dalam Menangani Perilaku Menyimpang. KONSELING RELIGI: Jurnal Bimbingan Konseling Islam, 4(1), 1-14. http://download.portalgaruda.org/article. php? article $=401126 \& \mathrm{val}=6785 \&$ title $=\mathrm{PE}$ NTINGNYA KECERDASAN SPIRITUAL DALAM MENANGANI PERILAKU MENYIMPANG

Anwar, S. S. (2014). Tanggung Jawab Pendidikan Dalam Perspektif Psikologi Agama. Psympathic: Jurnal Ilmiah Psikologi, 1(1), 11-21. https://doi.org/10.15575/psy.v1i1.463

Aridhona, J. (2017a). Hubungan Antara Kecerdasan Spiritual dan Kematangan Emosi dengan Penyesuaian Diri Remaja. INTUISI : Jurnal Psikologi Ilmiah, 9(3), 224-233.

https://doi.org/10.1017/CBO9781107415 324.004

Aridhona, J. (2017b). Hubungan Antara Kecerdasan Spiritual dan Kematangan Emosi Dengan Penyesuaian Diri Remaja. INTUISI : Jurnal Psikologi Ilmiah, 9(3), 224-233.

https://doi.org/10.1017/CBO9781107415 324.004

Arif, D., \& Pratama, N. (2019). Tantangan Karakter Di Era Revolusi Industri dalam Membentuk Kepribadian Muslim. AlTanzim: Jurnal Manajemen Pendidikan Islam, 3(1), 198-226.

Ashshidieqy, H. (2018). Hubungan
Kecerdasan Spiritual Terhadap Prestasi Belajar Siswa. JPPP - Jurnal Penelitian Dan Pengukuran Psikologi, 7(2), 68-75. https://doi.org/10.21009/jppp.072.02

Astuti, H. P. (2014). Smart Parenting: Upaya Peningkatan Kemam-puan Kognitif Dan Kreativitas Anak Di Kelurahan Banjarjo. Rekayasa, $\quad 12(1), \quad 33$. https://doi.org/Chronic ischaemic mitral regurgitation. Current treatment results and new mechanism-based surgical

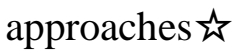

Azhari, R., Irmawita, I., \& Aini, W. (2018). Menggambarkan Manfaat Program Parenting Menurut Orang Tua di Kecamatan Lubuk Sikaping Kabupaten Pasaman. Spektrum: Jurnal Pendidikan Luar Sekolah (PLS), 1(1), 91. https://doi.org/10.24036/spektrumpls.v1i 1.9195

Baharun, H. (2017). Total Moral Quality: A New Approach for Character Education in Pesantren. Ulumuna, 21(1), 57-80.

Baharun, H. (2018). Curriculum Developmnent Trought Creative Lesson Plan. Jurnal Cendikia, 16(1), 41-62.

Candra, S. (2017). Pelaksanaan Parenting bagi Orang Tua Sibuk dan Pengaruhnya bagi Perkembangan Anak Usia Dini. Thufula, 5(2), 267-287.

Hanafi. (2016). Pemilihan Profesi Berdasarkan Kecerdasan Majemuk (Multiple Intelligence). Saintifika Islamica: Jurnal Kajian Keislaman, 3(1), $1-20$.

http://jurnal.uinbanten.ac.id/index.php/sa intifikaislamica/article/download/89/91/

Haryono, S. (2016). Pengaruh Kedisiplinan Siswa Dan Motivasi Belajar Terhadap Prestasi Belajar Siswa Pada Mata Pelajaran Ekonomi. Jurnal Ilmiah Kependidikan, 3(3), 261-274.

Hasan Baharun; Febri Deflia Finori. (2019). Smart Techno Parenting: Alternatif Pendidikan Anak pada Era Tekhnologi Digital. Jurnal Tatsqif, 17(1), 52-69. https://doi.org/10.20414/jtq.v17i1.625

Heru Kurniawan, R. H. (2016). Program Parenting Untuk Membentuk Karakter 
Anak Usia Dini Di Lembaga Pendidikan Anak Usia Dini. Aș-Sibyan; Jurnal Pendidikan Guru Raudlatul Athfal, 1(1), 32-33.

Jennah, M. (2019). Smart Parenting dalam Mengatasi Social Withdrawal pada Anak di Pondok Pesantren. Ta'allum: Jurnal Pendidikan Islam, 7(1), 45-72. https://doi.org/10.21274/taalum.2019.7.1. 45-72

Kesuma, G. C. (2017). Refleksi Model Pendidikan Pesantren dan Tantangannya Masa Kini. Tadris: Jurnal Keguruan Dan Ilmu Tarbiyah, 2(1), 67-79. https://doi.org/10.24042/tadris.v2i1.1740

Kurniasih, T. (2014). Tingkat Kepatuhan Tata Tertib Sekolah oleh Siswa Kelas VIII SMP Muhammadiyah 5 Yogyakarta. Jurnal Citizenship, 3(2), 165-178. https://doi.org/10.12928/citizenship.v3i2. 10672

M. Burhanuddin Ubaidillah. (2019). Pendidikan Islamic Parenting dalam Hadith Perintah Shalat. Jurnal Darussalam; Jurnal Pendidikan, Komunikasi Dan Pemikiran Hukum Islam, X(2), 62.

Mahmud, M. E., \& Suratman, S. (2019). Evaluasi Program Manajemen Pembelajaran Pada Sekolah Adiwiyata Kalimantan Timur. Al-Tanzim: Jurnal Manajemen Pendidikan Islam, 3(2), 8596. https://doi.org/10.33650/altanzim.v3i2.691

Maryam, S. (2018). Building Character Education Using Three Matra of Hasan Al-Banna'S Perspective in Pesantren. Jurnal Pendidikan Islam, 4(2), 51-62. https://doi.org/10.15575/jpi.v4i2.2422

Muallifah. (2013). Story telling Sebagai Metode Parenting Untuk Pengembangan Kecerdasan Anak Usia Dini. Jurnal Psikoislamika, $\quad$ 10(1), 100. https://doi.org/Chronic ischaemic mitral regurgitation. Current treatment results and new mechanism-based surgical approaches $\frac{1}{3}$

Mukhasin. (2014). Strategi Pengembangan Kecerdasan Spiritual Pada Santri Pondok
Pesantren Al-Hikmah Arjomulyo Adimulyo Kebumen. Sekolah Tinggi Agama Islam Negeri Purwokerto.

Mukhtar. (2014). Hubungan Kecerdasan Intelaktual, Emosialonal dan Spiritual dengan Kinerja Guru Pendidikan Jasmani. Jurnal Sport Pedagogy, 4(1), 9-13.

Muttaqiyathun, A. (2009). Hubungan Emotional Quotient, Intelectual Quotient dan Spiritual Quotient dengan Enterpreneur's Performance. Integritas JURNAL MANAJEMEN BISNIS, 2(3), 221-234.

Naim, N. (2014). Kecerdasan Spiritual: Signifikansi dan Strategi Pengembangan. Ta'allum, 2(1), 36-49.

Nooraeni, R. (2017). Implementasi Program Parenting Dalam Menumbuhkan Perilaku Pengasuhan Positif Orang Tua Di PAUD Tulip Tarogong Kaler Garut. Jurnal Pendidikan Luar Sekolah, 13(2), 31-41.

Nurochim. (2016). Sekolah Berbasis Pesantren Sebagai Salah Satu Model Pendidikan Islam Dalam Konsepsi Perubahan Sosial. Al-Tahrir, 16(1), 8182. https://doi.org/Chronic ischaemic mitral regurgitation. Current treatment results and new mechanism-based surgical approaches $i t$

Rahmad Setyawan, H. (2018). Hubungan antara Kecerdasan Spasial dengan Hasil Belajar Ilmu Pengetahuan Alam (IPA) Kelas VIII di SMP Negeri I Kemang Kabupaten Bogor. Jurnal Educate, 3(2), 206-216.

Rahmawati, U. (2016). Pengembangan Kecerdasan Spiritual Santri: Studi terhadap Kegiatan Keagamaan di Rumah TahfizQu Deresan Putri Yogyakarta. Jurnal Penelitian, 10(1), 97-124.

Rifa'i, M. (2017). Kebijakan Pendidikan Islam dalam Era Otonomi Daerah. AlTanzim: Jurnal Manajemen Pendidikan Islam, 1(1), 99-114.

Rifangatul Mahmudah. (2016). Hubungan Antara Kecerdasan Spiritual Dengan Kepribadian Santri Pondok Pesantren Alhidayah Karangsuci Purwokerto [Institut Agama Islam Negeri 
Purwokerto]. https://doi.org/Chronic ischaemic mitral regurgitation. Current treatment results and new mechanismbased surgical approaches 2 ‘

Rizzika Ozaria. (2018). Pelaksanaan Smart Parenting Education di Paud Terpadu Arraisyah Koba Bangka Tengah Bangka Belitung. Jurnal Program Studi PGRA, 4(2), 139-149. https://doi.org/Chronic ischaemic mitral regurgitation. Current treatment results and new mechanismbased surgical approaches 2$\}$

Rofiah, N. H. (2016). Menerapkan multiple intelligences dalam pembelajaran di sekolah dasar. Jurnal Dinamika Pendidikan Dasar, 8(1), 69-79. http://jurnalnasional.ump.ac.id/index.php /Dinamika/article/view/937/875

Rozana, A. A., Wahid, A. H., \& Muali, C. (2017). Smart Parenting Demokratis Dalam Membangun Karakter Anak. AlAthfal Jurnal Pendidikan Anak, 4(1), 116.

Sabiq, Z., \& Djalali, M. A. (2012). Kecerderdasan Emosi, Kecerdasan Spiritual dan Perilaku Prososial Santri Pondok Pesantren Nasyrul Ulum Pamekasan. Persona:Jurnal Psikologi Indonesia, 1(2), 53-65. https://doi.org/10.30996/persona.v1i2.21

Saufi, A., \& Hambali. (2019). Menggagas Perencanaan Kurikulum Menuju Sekolah Unggul. Al-Tanzim: Jurnal Manajemen Pendidikan Islam, 3(1), 29-54.

Setijaningsih, T., \& Matiningsih, W. (2014). The Effect of Parenting Program Towards Knowledge and Attitude of Parents for Giving Fundamental Needs of Children in Early Age. Jurnal Ners Dan Kebidanan (Journal of Ners and Midwifery), 1(2), 129-134. https://doi.org/10.26699/jnk.v1i2.art.p12 9-134

Siti Nur Mauanah, A. S. (2016). Parenting Education Sebagai Pendidikan Keluarga (Motif Keterlibatan Orang Tua Dalam Parenting Education). Paradigma, 4(1), $1-10$.

Sri W Rahmawati. (2017). Holistic Parenting: Pengasuhan Religius Berlandaskan Konsep Islam. Jurnal Psiko Utama, 5(2), 8. https://doi.org/Chronic ischaemic mitral regurgitation. Current treatment results and new mechanism-based surgical approaches is

Sukidi. (2004). Rahasia Sukses Hidup Bahagia, Kecerdasan Spiritual: Mengapa $S Q$ Lebih Penting Daripada IQ dan EQ. Gramedia.

Sukidi, H. (2002). Kecerdasan Spiritual: Mengapa SQ Lebih Penting Daripada IQ dan EQ. Jakarta: Gramedia Pustaka Utama.

Sukino, F. (2019). Internalization of Students , Scientific Attitudes through Islamic Education in Madrasah Aliyah. Tadris: Jurnal Keguruan Dan Ilmu Tarbiyah, 4(1), 97-106. https://doi.org/10.24042/tadris.v4i1.4201

Wibowo, C. T. (2015). Analisis Pengaruh Kecerdasan Emosional (EQ) dan Kecerdasan Spiritual (SQ) pada Kinerja Karyawan. Jurnal Bisnis Dan Manajemen, 15(1), 1-16.

Yuki Widiasari, D. P. (2017). Jurnal Indria. Pengaruh Bermain Sianida (Suara, Irama, Dan Nada) Terhadap Kecerdasan Musik Anak Usia Dini, 7255(2), 68-79.

Zulfaizah. (2018). Revitalisasi pendidikan agama dalam pembentukan karakter peserta didik di madrasah. ELEMENTARY, 6(1), 43-62. 